\title{
Immunological tolerance: one of biology's most intriguing mysteries
}

\author{
Thomas E. STARzL, MD, PHD, AND NORIKo Murase, MD
}

W hy is it that so many organ recipients, especially recipients of a liver, are able to survive without taking immunosuppressive drugs? The first recipient of a liver at Baylor, Amie Garrison, was 5 years old at the time of her transplantation in 1984. When she was age 15, however, she rebelled and refused to continue taking her medication. We feared the worst, but happily she has survived off drugs for more than 5 years. Furthermore, she is now married and has a young child of her own. What happened?

Survival without immunosuppressive medication is not uncommon. Indeed, at our clinic in Pittsburgh we deliberately wean liver transplant recipients from immunosuppressive therapy under close supervision $(1,2)$-quite a different situation than noncompliance. We believe that patients who can survive with stable graft function off immunosuppressive therapy have genuine immunological donor-specific tolerance and can anticipate a normal life expectancy.

Another dramatic case also illustrates my point. Approximately 13 years ago, a child from a prominent Eurasian family became ill on a flight from Hong Kong to Manila. She had a hepatoma of the liver which ruptured, causing a nearly fatal hemorrhage. Her family had the plane rerouted to Los Angeles and from there to Pittsburgh, where we performed a liver transplantation. Tumor from the lesion was thought to have seeded throughout the abdomen. The prognosis appeared hopeless.

Postoperatively, the child received chemotherapy, and after a stormy course that included a bout of severe pancytopenia, she returned home and grew up. She not only stopped taking immunosuppression medication but also became a fashion cover girl and is now on her way to becoming a world-class ballet dancer (as was her mother before her). Like Amie Garrison, this patient has a normal life expectancy. She has acquired tolerance.

Although it was not recognized as such, tolerance has been a theme throughout the entire modern age of organ transplantation. This was belatedly acknowledged at a meeting last March at the University of California, Los Angeles (UCLA). The purpose of the conference was to reach a consensus about the milestones that had made transplantation a thriving clinical specialty. Eleven early workers in clinical organ and tissue transplantation contributed to the program. Professor Carl Groth (Karolinska Institute, Stockholm) was invited to be chairman of the consensus deliberations, the conclusions from which are being published (3).
The participants included histocompatibility specialists Jean Dausset, MD, Paul Terasaki, PhD, and Jon J. Van Rood, MD; early investigators of acquired tolerance (Leslie Baruch Brent, $\mathrm{PhD}$ ) and drug immunosuppression (Robert S. Schwartz, MD); bone marrow transplanters Robert A. Good, MD, and E. Donnall Thomas, MD; and organ transplant surgeons Roy Calne, MD, Joseph E. Murray, MD, Norman E. Shumway, MD, and myself.

The 4 surgeons accounted for the first successful transplantations of the kidney, liver, and heart. Murray became a 1990 Nobel laureate. Good performed the first successful bone marrow transplantation in 1968. Thomas was a Nobel laureate in 1990 for his studies of bone marrow transplantation for a variety of diseases. Leslie Brent is the Brent of the famous British team known in the 1950s as the "holy trinity" of transplantation immunology. Schwartz was the first to show the immunosuppressive qualities of 6-mercaptopurine (6-MP) and azathioprine (4). For his discovery of the first human histocompatibility locus antigen (HLA) (5), Dausset received a Nobel prize. Terasaki and Van Rood introduced tissue matching into clinical transplantation.

\section{MILESTONES VS TURNING POINTS Milestones}

The participants placed transplantation milestones in 2 categories (Table 1). The first consisted of generic advances that were applicable to all kinds of allografts. Progressively more effective immunosuppressive agents and drug regimens headed this list. Methods of tissue and organ preservation and histocompatibility matching also qualified. Although broadly applicable surgical techniques were not listed, they could be exemplified by the development nearly 100 years ago by Alexis Carrel of techniques for vascular surgical anastomoses (6).

The second category of milestones was organ- or cellspecific. This consisted of the first examples of long allograft and patient survival ( $\geq 6$ months) after transplantation of various

From the Thomas E. Starzl Transplantation Institute, University of Pittsburgh Medical Center, Pittsburgh, Pennsylvania.

Aided by project grant no. DK 29961 from the National Institutes of Health, Bethesda, Maryland.

Presented at grand rounds, Baylor University Medical Center, April 21, 1999.

Corresponding author: Thomas E. Starzl, MD, PhD, University of Pittsburgh Medical Center, 3601 Fifth Avenue, 4C Falk Clinic, Pittsburgh, Pennsylvania 15213. 
Table 1. Transplantation milestones

\section{Generic milestones (applicable to all tissues and organs)}

A. First use of individual immunosuppressants (all eventually combined with adrenal cortical steroids)

1. Total body irradiation (1959)

2. 6-MP and azathioprine (1960-1962)

3. Other myelotoxic agents (1960-1965)

4. Adrenal cortical steroids (anecdotally, 1955-1961; systematically, 1962-1963)

5. First effective tolerance-inducing cocktail (azathioprine/prednisone) (1962-1963)*

6. Antilymphoid antibodies (antilymphocyte globulin) (1966)

7. Cyclosporine (1978-1979)

8. Tacrolimus (1989)

B. Tissue and organ preservation

1. Hypothermia per se

(a) Surface cooling (1960)

(b) Cold fluid infusion (1962-1963)

2. Special infusates; slush preservation
(a) Lactated Ringer's solution (1962-1963)
(b) Low-molecular-weight dextran (1963)
(c) Mimicking intracellular composition (1966)
(d) Mimicking extracellular composition (1973)
(e) UW solution (1987)

3. Artificial postmortem circulation

(a) Whole cadaver (1963)

(b) Isolated organ $(1966)^{\dagger}$

C. Clinical histocompatibility matching

1. Lymphocyte culture LMLR (1963)

2. Serologic (1964)

3. Molecular (1990s)

II. Generic clinical milestones (tissue- or organ-defined milestones: first clinical survival $>6$ months)

A. Kidney

1. Isografts (1954)

2. Allografts (1959)

B. Bone marrow

1. Isografts (1955)

2. Allografts $(1963,1968)$

C. Extrarenal organs

1. Liver (1967)

2. Heart (1968)

3. Lung (1968)

4. Pancreas (1969)

5. Intestine (in multivisceral grafts, 1987; segmental, 1988; complete, 1989)

${ }^{*}$ Generic strategy applicable with subsequent drugs.

${ }^{\dagger}$ First experiments by A. Carrell and C. A. Lindberg (1935).

kinds of human tissues and organs. This objective was accomplished with the kidney in January 1959 (7), and with the liver (8), heart (9), lung (10), and pancreas (11) in that order between July 1967 and June 1969. Completely successful bone marrow transplantation was not done until $1968(12,13)$, and intestinal transplantation was delayed until the late 1980 s.

\section{Turning points}

The foregoing milestones in both generic and organ-specific categories, and dozens of lesser ones, are important. However, as the layers of history were peeled away it became apparent that there actually were only 2 seminal turning points in the evolution of clinical transplantation: that allograft tolerance can be acquired and that organs are inherently tolerogenic (14-16). The stage for these turning points had been set during the Second World War with the demonstration by Medawar (a basic scientist) and Gibson (a plastic surgeon) that rejection is an immune response (17). However, rejection was considered for the ensuing decade to be one of the most powerful and irrevocable reactions in biology and therefore uncontrollable.

The resulting pessimism about the prospects of clinical transplantation had to be modified in 1953 when Billingham, Brent, and Medawar demonstrated the induction of chimerismassociated acquired neonatal tolerance (18). This was the first turning point. The tolerance induced in neonatal mice with splenocyte or bone marrow cell infusion mimicked the natural hematolymphopoietic chimerism in freemartin cattle reported nearly a decade earlier by Owen (19). The neonatal mouse experiments escalated in a straight line to clinical bone marrow transplantation $(12,13,20)$.

The second turning point was the clinical demonstration in the early 1960s that tissue and organ allografts could "self-induce" tolerance when combined with immunosuppression (21). This discovery galvanized a revolution in clinical organ transplantation. The downside, however, was the erroneous conclusion that the "acceptance" and long-term survival of organs occurred by different mechanisms than the chimerism-dependent tolerance induced by bone marrow and other hematolymphopoietic allografts.

The ostensible differences between bone marrow transplantation and organ transplantation (Figure 1) seemed too great to permit any other conclusion. These differences included 1) dependence on HLA matching for successful bone marrow transplantation but not for organ transplantation, 2) risk vs freedom of risk from graft-vs-host disease (GVHD), 3) frequency vs infrequency of achievement of drug-free status, and 4) a semantic distinction between the tolerance of bone marrow transplantation and the acceptance of organ grafts.

As it turned out, all of these differences were explained by hematopoietic cytoablation of the bone marrow recipient (initially with total body irradiation, later with cytotoxic drugs) but not of the organ recipient. When this finally was recognized in the 1990s, the linkage between organ transplantation and bone marrow transplantation was established. In addition, the relation of both varieties of transplantation to the neonatal tolerance described by Billingham, Brent, and Medawar was obvious. The epiphany was largely dependent on the demonstration of lowlevel donor leukocyte chimerism in liver allograft recipients (1416). Consequently, it will be useful here to review how liver transplantation evolved.

\section{THE LATE 1950s}

Turning the clock back more than 40 years, my personal involvement in transplantation began with the development in 1958 and 1959 of techniques for canine liver transplantation, 


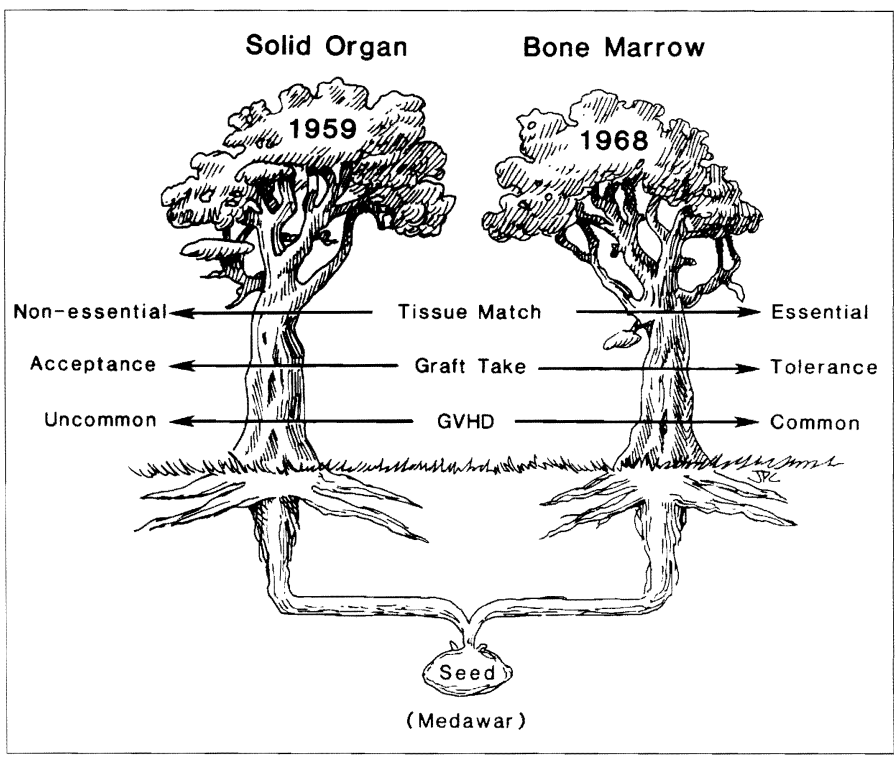

Figure 1. The division of transplantation into two separate disciplines, caused by different treatment policies.

alone or as part of multivisceral grafts $(22,23)$, paralleling similar independent investigations in Boston by Francis D. Moore (24). This was at first an exercise in surgical technique. Although adrenal cortical steroids and total body irradiation were known to be immunosuppressive, survival for as long as 3 months had not been achieved in any species with any kind of organ allograft.

Our laboratory efforts took on a different meaning with the demonstration in 1959 by Schwartz and Damashek $(4,25)$, promptly confirmed by Good's Minnesota team (26), that 6-MP prolonged the survival of skin grafts in rabbits without the need for the kind of bone marrow depression caused by irradiation. When in 1960 Calne in London (27) and Zukoski in Richmond, Virginia (28), reported that 6-MP therapy prolonged kidney allograft survival in dogs, the possibility of similarly treating liver recipients was obvious. In fact, this was attempted clinically less than 3 years later, following advances with immunosuppression made in human kidney recipients.

\section{THE PATHFINDER KIDNEY}

Between January 26, 1959, and March 1, 1963, the date of our first attempt to replace a human liver, Murray in Boston (7) and the French teams of Hamburger (29) and Kuss (30) had produced 6 clinical examples of kidney allograft survival exceeding 6 months after pretreatment with total body irradiation (Table 2). Although 4 of these patients soon died, the 2 recipients of fraternal twin kidneys survived more than 20 years. Importantly, the seventh kidney recipient was 11 months posttransplantation by March 1, 1963, after treatment by Murray from the outset (April 1962) with the 6-MP analogue azathioprine (31). This allograft functioned for 17 months.

It had been learned, however, that to achieve more than occasional success in either dogs or humans, azathioprine needed a partner drug. This proved to be dose-maneuverable prednisone (21), which we knew from our canine kidney and liver transplant studies could reverse $90 \%$ of the rejections developing under azathioprine. Unbeknownst to us, this steroid effect already had
Table 2. Kidney transplantation $\geq 6$ months survival as of March 1963

\begin{tabular}{ccccc}
\hline Case & City & Date & Donor & Survival (months) $^{\star}$ \\
\hline 1 & Boston $^{\dagger}$ & $1-24-59$ & Frat twin & $>50$ \\
2 & Paris $^{\dagger \dagger}$ & $6-29-59$ & Frat twin & $>45$ \\
3 & Paris & $6-22-60$ & Unrelated $^{\S}$ & 18 (died) \\
4 & Paris & $12-19-60$ & Mother $^{\S}$ & 12 (died) \\
5 & Paris & $3-12-61$ & Unrelated $^{\S}$ & 18 (died) \\
6 & Paris & $2-12-62$ & Cousin $^{\S}$ & $>13$ \\
7 & Boston & $4-5-62$ & Unrelated & 11 \\
\hline
\end{tabular}

* The kidneys in patients 1, 2, and 6 functioned for 20.5, 25, and 15 years, respectively. Patient 7 rejected his graft after 17 months and died after return to dialysis.

${ }^{\dagger}$ Boston: J. E. Murray (1 and 7).

${ }^{\dagger \dagger}$ Paris: J. Hamburger $(2,4$, and 6); R. Kuss ( 3 and 5$)$.

$\S$ Adjunct steroid therapy.

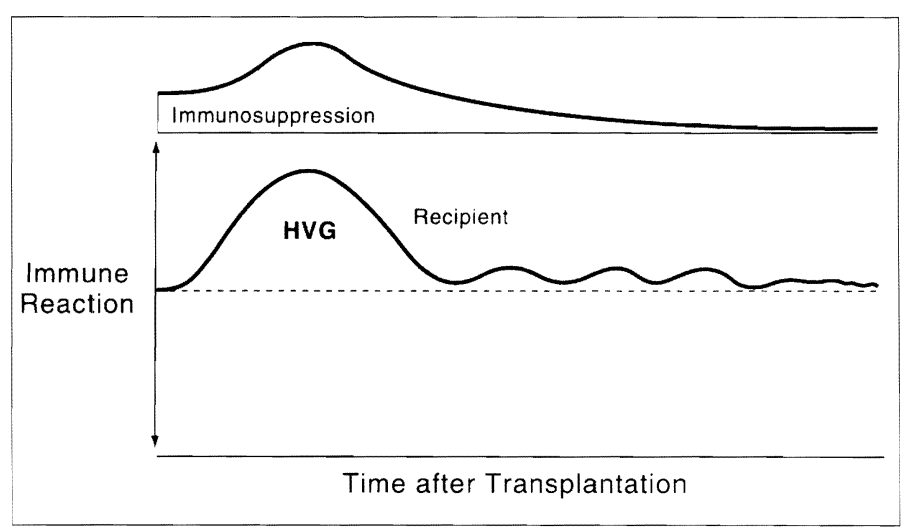

Figure 2. Historical view of events after successful organ transplantation: rejection, its reversal, and the development of donor-specific nonreactivity.

been seen in the autumn of 1960 by Willard Goodwin in a kidney recipient at UCLA in whom bone marrow depression had been induced with myelotoxic doses of methotrexate and cyclophosphamide (32). Regrettably, the case was not reported until 1963 , by which time the pioneer UCLA program had closed down because of the early deaths of all the other recipients.

In the meanwhile, we had begun our clinical kidney transplant program in the autumn of 1962, using azathioprine plus prednisone. As reported in October 1963 (21), 8 of our first 10 kidney recipients had prolonged graft survival. This was the first successful series of kidney transplantations. Two of these patients, now old men in their 37 th posttransplant year, bear the longest continuously functioning allografts in the world. As has been expected from the observations in dogs, rejection was regularly reversible. More importantly, there was also clear evidence that the transplanted kidneys had self-induced variable donor-specific tolerance.

The most convincing evidence of tolerance was the frequent diminution of need for maintenance immunosuppression after the development of rejection and its reversal (Figure 2). The donor-specific nonreactivity was complete enough to allow many patients to go home to an unrestricted environment. The third 

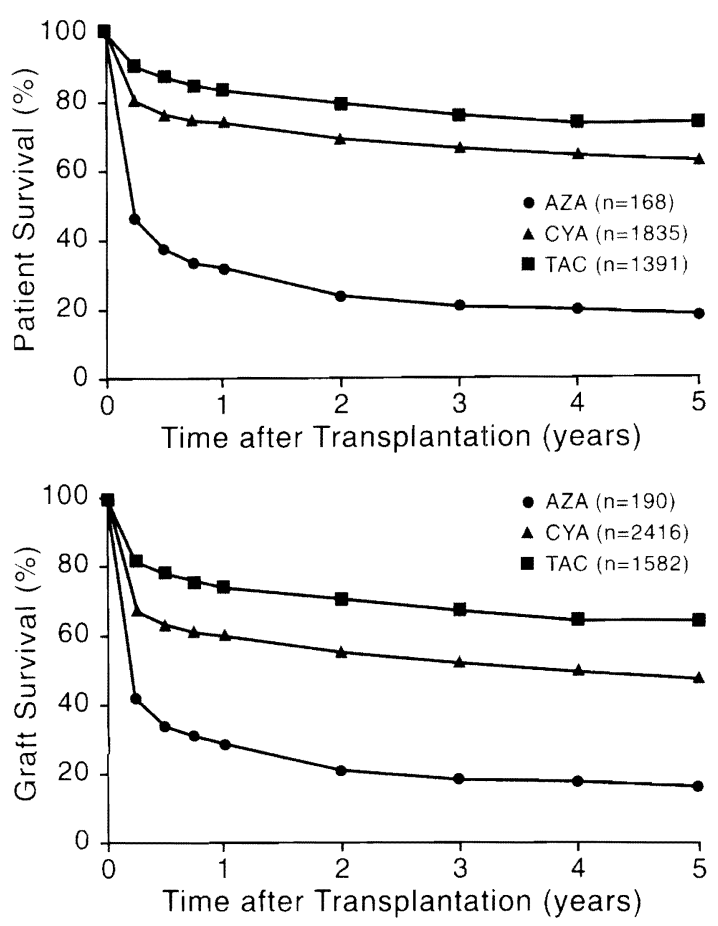

Figure 3. The 3 eras of orthotopic liver transplantation at the Universities of Colorado (1963-1980) and Pittsburgh (1981-1993), defined by azathioprine, cyclosporine, and tacrolimus (FK 506)-based immune suppression. Similar but less dramatic stepwise improvement has been seen with all organs. Top family of curves: patient survival. Bottom family: graft survival.

patient in this series stopped all medications about 1 year after transplantation and has been drug free for more than a third of a century (33).

\section{LIVER TRANSPLANTATION}

Our early experience with kidney transplantation, combined with more than 5 years' investigation of canine liver transplantation, prompted our attempts to replace the human liver, the first vital extrarenal organ to be transplanted clinically. When the first 3 patients (34), single patients in Boston (35) and Paris (36), and an additional 2 recipients in our Colorado program (37) all died within 23 posttransplant days, clinical liver transplantation ceased worldwide. During the $31 / 2$-year self-imposed moratorium, we developed and introduced horse antihuman antilymphocyte globulin clinically, first testing it in kidney recipients as a perioperative adjunct to azathioprine and prednisone (38).

Armed with the encouraging results in the kidney trial, the liver program was restarted in July 1967, using the same 3-drug immunosuppression (azathioprine, prednisone, and antilymphoctye globulin) that had been tested in kidney recipients. A number of long survivals were obtained ( $>1$ year), mostly of children (39). A 33-year-old woman (then a 3-year-old child with biliary atresia and a hepatoma) is the longest surviving liver recipient in the world, now in her 30th posttransplant year.

Another 13 years would pass before this kind of result became regularly attainable. The improvement in transplantation of the liver and other organs has occurred in 3 distinct drug-

\section{Table 3. Central therapeutic dogma}
1. Baseline therapy with one or two drugs*
2. Secondary adjustments with steroids or antilymphoid agents
3. Case-to-case trial (and potential error) of weaning

*Baseline agents: azathioprine, cyclophosphamide, cyclosporine, cyclosporineazathioprine, FK 506, FK 506-azathioprine.

defined eras: azathioprine-based therapy, cyclosporine-based therapy $(40,41)$, and tacrolimus (FK 506) (42) (Figure 3). Because retransplantation became increasingly more reliable with the better immunosuppression, patient survival was successively better than graft survival. With the advent of tacrolimus, the first immunosuppressant to be evaluated primarily with liver transplantation, intestinal transplantation became a viable clinical option.

\section{EXPLANATION OF "ORGAN ACCEPTANCE"}

Despite the diversity of azathioprine, cyclosporine, tacrolimus, and other immunosuppressants, the basic pattern of immunologic confrontation and involution remained the same. With individualized treatment adjustments guided by evidence of graft rejection, graft acceptance could be engineered as described in Table 3. What was being accomplished with this strategy? The answer was discovered in 1992.

In the spring of 1992, 25 liver and 5 kidney recipients who had survived with functioning grafts for 10 to 30 years were brought to Pittsburgh for restudy. In addition to blood sampling, open biopsy was obtained of the transplanted organs; of the recipient lymph nodes and skin; and, when indicated, of other host organs, including the heart, intestine, and bone marrow. Small numbers of donor leukocytes were found in the host peripheral lymphoid and nonlymphoid tissues or blood of all 30 patients (14, $15)$. The donor cells were identified by study of the HLA antigens or sex karyotype with immunocytochemical methods. The findings were confirmed with polymerase chain reaction studies. The chimerism included the prominent presence of dendritic cells.

Now, we realized that organ transplantation involved a double immune reaction-which had both a host-vs-graft response and a covert graft-vs-host response (Figure 4). Because the dominant immune reaction following organ transplantation usually is that of the host, the common complication is rejection of the graft. However, serious or lethal GVHD is not rare after transplantation of leukocyte-rich organs like the liver. For allograft acceptance (and tolerance) to occur (rather than rejection or GVHD), the seminal tolerogenic mechanism was postulated to be "[widespread] responses of coexisting donor and recipient immune cells, each to the other, causing reciprocal clonal expansion, followed by peripheral clonal deletion" $(14,15)$.

By 1998, compelling evidence had accumulated from controlled animal experiments confirming this hypothesis, as summarized in a recent review coauthored with Rolf Zinkernagel (16). Organ and bone marrow "acceptance" were related forms of acquired tolerance-not fundamentally different than the 


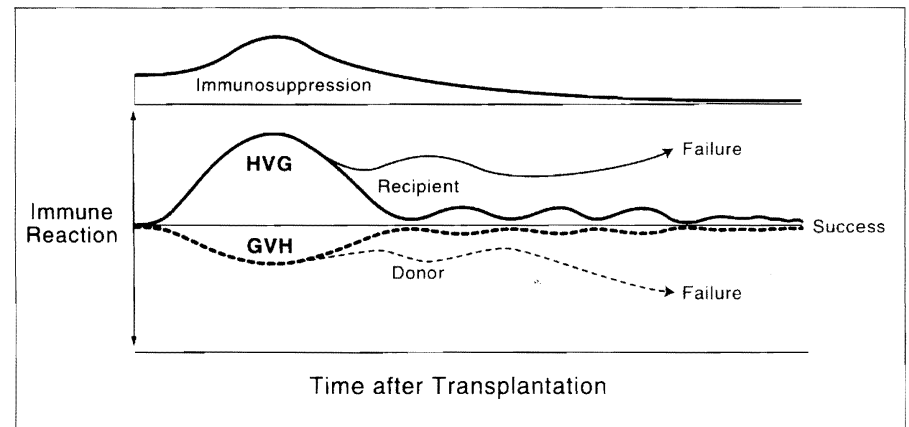

Figure 4. Contemporaneous host-vs-graft and graft-vs-host reactions that occur after transplantation. Treatment failure is defined as the inability to control one of the reactions or sometimes both. Acute reciprocal clonal exhaustion after successful transplantation is maintained subsequently by chimerism-dependent low-grade stimulation of both leukocyte populations that may wax and wane.

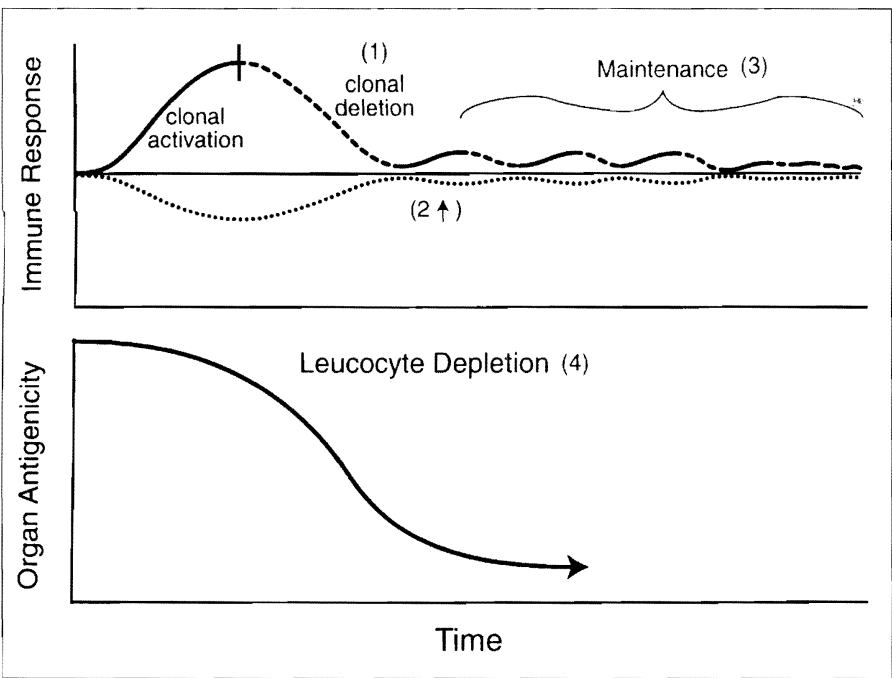

Figure 5. The 4 events that occur in close temporal approximation when there is successful organ engraftment: above, double acute clonal exhaustion (numbers 1 and 2) and subsequent maintenance clonal exhaustion (3) plus, below, loss of organ immunogenicity due to depletion of the graft's passenger leukocytes (4).

major histocompatibility (MHC)-restricted antigen-specific tolerance that can be induced by noncytopathic viruses and other microorganisms (16). However, the response to an organ allograft is made more complex than that to a noncytopathic microorganism by the presence of immunocompetent donor cells and the consequent double immune reaction (graft vs host as well as host vs graft).

Clonal exhaustion and an ancillary mechanism of "immune indifference," both regulated by the migration and localization of the donor leukocytes, were responsible for the 4 interrelated events shown in Figure 5. These must occur in close temporal proximity for successful organ engraftment: double acute clonal exhaustion; maintenance clonal exhaustion, which waxes and wanes; and loss of organ immunogenicity as the passenger leukocytes depart from the graft.

The reciprocal nullification of the interreactive immune responses explained the poor prognostic value of tissue matching for organ transplantation (43). This nullification effect also ex-
Table 4. Effectors involved in response to cytopathic parasites and discordant xenografts

\begin{tabular}{lc}
\hline The first line of defense & Nonspecific or less specific effectors \\
Interferons & Complement \\
Macrophages & Early interleukins \\
$\gamma / \delta T$ cells & Phagocytes \\
Natural killer (NK) cells & \\
B cells & \\
\hline
\end{tabular}

plains why GVHD is so uncommon, even after organ transplantation with engraftment of leukocyte-rich organs like the liver and intestine, and why it is safe to infuse adjunct donor bone marrow in organ recipients providing the patients are not immunologically weakened in advance by cytoablation or other means $(15,33)$.

It follows that conventional bone marrow transplantation is a mirror image of the events after organ transplantation and is also governed by antigen migration and localization. The host leukocytes are not all eliminated by pretransplant cytoablation $(44,45)$. The weak host-vs-graft reaction mounted by those remaining recipient cells and the parallel graft-vs-host reaction of the dominant population of donor cells can eventually result in reciprocal tolerance $(16,46)$. It might be added that these same events transpire in the historically important "mixed chimerism" tolerance models. We had in fact returned full circle to the first observations of natural tolerance in freemartin cattle reported in Science 55 years earlier by Ray Owen (19).

\section{XENOTRANSPLANTATION}

There is no MHC-restricted safety valve for cytopathic microorganisms, which are typically extracellular and generate the full resources of the innate as well as the adaptive immune system $(16,47,48)$. An uncontrollable innate immune response involving the effectors shown in Table 4 is provoked by discordant xenografts expressing the Gal- $\alpha$ Gal epitope, an epitope that is also found on numerous cytopathic bacteria, protozoa, and viruses. The clinical use of such discordant animal donors (e.g., pigs) will require either changing the xenogeneic epitope to one that mimics a noncytopathic profile or eliminating the xenogeneic epitope $(16,49)$.

\section{SUMMARY}

Thus, the 2 seminal turning points that allowed the clinical emergence of transplantation turned out to involve the same, not different, tolerance mechanisms. This has explained historical enigmas, including the meaning of allograft acceptance, which is simply a form of acquired tolerance. This paradigm also establishes a better context for the design of experiments and therapies yet to come.

\section{References}

1. Ramos HC, Reyes J, Abu-Elmagd K, Zeevi A, Reinsmoen N, Tzakis A, Demetris AJ, Fung JJ, Flynn B, McMichael J, Ebert F, Starzl TE. Weaning of immunosuppression in long-term liver transplant recipients. Transplantation 1995;59:212-217. 
2. Mazariegos GV, Reyes J, Marino IR, Demetris AJ, Flynn B, Irish W, McMichael J, Fung JJ, Starzl TE. Weaning of immunosuppression in liver transplant recipients. Transplantation 1997;63:243-249.

3. Groth CG, Brent LB, Calne RC, Dausset J, Good RA, Murray JE, Shumway NE, Schwartz RS, Starzl TE, Terasaki PI, Thomas ED, Van Rood JJ. Historical landmarks in clinical transplantation: conclusions from the consensus conference held at University of California, Los Angeles (UCLA). World J Surg. In press.

4. Schwartz R, Dameshek W. Drug-induced immunological tolerance. Nature 1959;83:1682-1683.

5. Dausset J. Iso-leuco-anticorps. Acta Haematol 1958;20:156-166.

6. Carrel A. The operative technique for vascular anastomoses and transplantation of viscera. Lyon Medicine 1902;98:859-864.

7. Merrill JP, Murray JE, Harrison JH, Friedman EA, Dealy JB Jr, Dammin GJ. Successful homotransplantation of the kidney between non-identical twins. N Engl J Med 1960;262:1251-1260.

8. Starzl TE, Groth CG, Brettschneider L, Moon JB, Fulginiti VA, Cotton EK, Porter KA. Extended survival in 3 cases of orthotopic homotransplantation of the human liver. Surgery 1968;63:549-563.

9. Barnard CN. What we have learned about heart transplants. J Thorac Cardiovasc Surg 1968;56:457-468.

10. Derom F, Barbier F, Ringoir S, Versieck J, Rolly G, Berzsenyi G, Vermeire P, Vrints L. Ten-month survival after lung homotransplantation in man. $J$ Thorac Cardiovasc Surg 1971;61:835-846.

11. Lillehei RC, Simmons RL, Najarian JS, Weil R, Uchida H, Ruiz JO, Kjellstrand CM, Goetz FC. Pancreatico-duodenal allotransplantation: experimental and clinical experience. Ann Surg 1970;172:405-436.

12. Gatti RA, Meuwissen HJ, Allen HD, Hong R, Good RA. Immunological reconstitution of sex-linked lymphopenic immunological deficiency. Lancet 1968;2:1366-1369.

13. Bach FH, Albertini RJ, Joo P, Anderson JL, Bortin MM. Bone-marrow transplantation in a patient with the Wiskott-Aldrich syndrome. Lancet 1968;2:1364-1366.

14. Starzl TE, Demetris AJ, Murase N, Ildstad S, Ricordi C, Trucco M. Cell migration, chimerism, and graft acceptance. Lancet 1992;339:1579-1582.

15. Starzl TE, Demetris AJ, Trucco M, Murase N, Ricordi C, Ildstad S, Ramos H, Todo S, Tzakis A, Fung JJ, Nalesnik M, Zeevi A, Rudert WA, Kocova $M$. Cell migration and chimerism after whole-organ transplantation: the basis of graft acceptance. Hepatology 1993;17:1127-1152.

16. Starzl TE, Zinkernagel RM. Antigen localization and migration in immunity and tolerance. N Engl J Med 1998;339:1905-1913.

17. Gibson T, Medawar PB. The fate of skin homografts in man. J Anatomy 1943;77:299-310.

18. Billingham RE, Brent L, Medawar PB. "Actively acquired tolerance" of foreign cells. Nature 1953;172:603-606.

19. Owen RD. Immunogenetic consequences of vascular anastomoses between bovine twins. Science 1945;102:400-401.

20. Thomas ED, Storb R, Clift RA, Fefer A, Johnson FL, Neiman PE, Lerner KG, Glucksberg H, Buckner CD. Bone-marrow transplantation. N Engl J Med 1975;292:832-843, 895-902.

21. Starzl TE, Marchioro TL, Waddell WR. The reversal of rejection in human renal homografts with subsequent development of homograft tolerance. Surg Gynecol Obstet 1963;117:385-395.

22. Starzl TE, Kaupp HA Jr, Brock DR, Lazarus RE, Johnson RV. Reconstructive problems in canine liver homotransplantation with special reference to the postoperative role of hepatic venous flow. Surg Gynecol Obstet 1960;111:733-743.

23. Starzl TE, Kaupp HA Jr. Mass homotransplantation of abdominal organs in dogs. Surg Forum 1960;11:28-30.

24. Moore FD, Wheeler HB, Dimissianos HV, Smith LL, Balankura O, Abel $\mathrm{K}$, Greenberg JB, Dammin GJ. Experimental whole organ transplantation of the liver and of the spleen. Ann Surg 1960;152:374-387.

25. Schwartz R, Dameshek W. The effects of 6-mercaptopurine on homograft reactions. J Clin Invest 1960;39:952-958.

26. Meeker W, Condie R, Weiner D, Varco RL, Good RA. Prolongation of skin homograft survival in rabbits by 6-mercaptopurine. Proc Soc Exp Biol Med 1959;102:459-461.
27. Calne RY. The rejection of renal homografts: inhibition in dogs by 6 -mercaptopurine. Lancet 1960;1:417-418.

28. Zukoski CF, Lee HM, Hume DM. The prolongation of functional survival of canine renal homografts by 6-mercaptopurine. Surg Forum 1960;11:470472.

29. Hamburger J, Vaysse J, Crosnier J, Auvert J, Lalanne CL, Hopper J Jr. Renal homotransplantation in man after radiation of the recipient. Am J Med 1962;32:854-871.

30. Kuss R, Legrain M, Mathe G, Nedey R, Camey M. Homologous human kidney transplantation. Experience with six patients. Postgrad Med J 1962; 38:528-531.

31. Murray JE, Merrill JP, Harrison JH, Wilson RE, Dammin GJ. Prolonged survival of human-kidney homografts by immunosuppressive drug therapy. $N$ Engl J Med 1963;268:1315-1323.

32. Goodwin WE, Kaufman JJ, Mims MM, Turner RD, Glassock R, Goldman R, Maxwell MM. Human renal transplantation. I. Clinical experience with six cases of renal homotransplantation. J Urology 1963;89:13-24.

33. Starzl TE, Demetris AJ, Murase N, Trucco M, Thomson AW, Rao AS. The lost chord: microchimerism and allograft survival. Immunol Today 1996; 17:577-584, discussion 588.

34. Starzl TE, Marchioro TL, Von Kaulla KN, Hermann G, Brittain RS, Waddell WR. Homotransplantation of the liver in humans. Surg Gynecol Obstet 1963;117:659-676.

35. Moore FD, Birtch AG, Dagher F, Veith F, Krisher JA, Order SE, Shucart WA, Dammin GJ, Couch NP. Immunosuppression and vascular insufficiency in liver transplantation. Ann NY Acad Science 1964;120:729-738.

36. Demirleau, Noureddine, Vignes, Prawerman, Reziciner, Larraud, Louviers. Attempted hepatic homograft [article in French]. Mem Acad Chir (Paris) 1964;90:177-179.

37. Starzl TE, Marchioro TL, Rowlands DT Jr, Kirkpatrick CH, Wilson WEC, Rifkind D, Waddell WR. Immunosuppression after experimental and clinical homotransplantation of the liver. Ann Surg 1964;160:411-439.

38. Starzl TE, Marchioro TL, Porter KA, Iwasaki Y, Cerilli GJ. The use of heterologous antilymphoid agents in canine renal and liver homotransplantation and in human renal homotransplantation. Surg Gynecol Obstet 1967;124:301-308.

39. Starzl TE, Groth CG, Brettschneider L, Penn I, Fulginiti VA, Moon JB, Blanchard H, Martin AJ Jr, Porter KA. Orthotopic homotransplantation of the human liver. Ann Surg 1968;168:392-415.

40. Calne RY, White DJ, Thiru S, Evans DB, McMaster P, Dunn DC, Craddock GN, Pentlow BD, Rolles K. Cyclosporin A in patients receiving renal allografts from cadaver donors. Lancet 1978;2:1323-1327.

41. Starzl TE, Klintmalm GB, Porter KA, Iwatsuki S, Schroter GP. Liver transplantation with use of cyclosporin $\mathrm{A}$ and prednisone. $N$ Engl J Med 1981;305:266-269.

42. Starzl TE, Todo S, Fung J, Demetris AJ, Venkataramman R, Jain A. FK 506 for liver, kidney, and pancreas transplantation. Lancet 1989;2:1000-1004.

43. Starzl TE, Rao AS, Trucco M, Fontes P, Fung JJ, Demetris AJ. Explanation for loss of the HLA matching effect. Transplant Proc 1995;27:57-60.

44. Przepiorka D, Thomas ED, Durnam DM, Fisher L. Use of a probe to repeat sequence of the $\mathrm{Y}$ chromosome for detection of host cells in peripheral blood of bone marrow transplant recipients. Am J Clin Pathol 1991;95:201206.

45. Wessman M, Popp S, Ruutu T, Volin L, Cremer T, Knuutila S. Detection of residual host cells after bone marrow transplantation using non-isotopic in situ hybridization and karyotype analysis. Bone Marrow Transplant 1993; 11:279-284.

46. Starzl TE, Demetris AJ. Transplantation milestones. Viewed with one- and two-way paradigms of tolerance. JAMA 1995;273:876-879.

47. Zinkernagel RM. Immunology taught by viruses. Science 1996;271:173-178.

48. Zinkernagel RM, Ehl S, Aichele P, Oehen S, Kundig T, Hengartner H. Antigen localisation regulates immune responses in a dose- and timedependent fashion: a geographical view of immune reactivity. Immunol Rev 1997;156:199-209.

49. Starzl TE, Rao AS, Murase N, Fung J, Demetris AJ. Will xenotransplantation ever be feasible? J Am Coll Surg 1998;186:383-387. 